\title{
UJI BERKELANJUTAN EKOLOGI CACING TANAH Lumbricus rubellus PADA BAHAN INDUK TANAH TAMBANG EMAS DENGAN MEMANFAATKAN KOMPOS
}

\author{
Frengky Kosho \\ Zetly Estefanus Tamod \\ Wenny Tilaar
}

\begin{tabular}{ll}
\hline Naskah diterima melalui Email agrisosioekonomi@unsrat.ac.id & $:$ Rabu, 8 Juli 2020 \\
Disetujui diterbitkan & : Kamis, 16 Juli 2020 \\
\hline
\end{tabular}

\begin{abstract}
This study aims to determine the effect of the provision of compost, cow manure and chicken manure on the ecological sustainability of earthworms (Lumbricus rubellus), on gold mine soil parent material; and on the initial growth of upland paddy unsrat variety 1. This research was carried out in May to July 2019 at the Greenhouse of the Faculty of Agriculture, Sam Ratulang University in Manado. The design used in this study used a completely randomized design (CRD) method with 3 treatments and 3 replications. The results showed that the provision of compost, cow manure and chicken manure gave good results on ecological sustainability of earthworms (Lumbricus rubellus), on fertility in gold mine soil parent material, and on early growth of upland paddy unsrat variety $1 .{ }^{* e p r m *}$
\end{abstract}

Keywords: decomposition process, soil fertility, upland paddy unsrat variety 1

\begin{abstract}
ABSTRAK
Penelitian ini bertujuan untuk mengetahui pengaruh pemberian kompos, kotoran sapi dan kotoran ayam terhadap keberlanjutan ekologis cacing tanah (Lumbricus rubellus), bahan induk tanah tambang emas; dan pertumbuhan awal padi gogo varietas unsrat 1 . Penelitian ini dilaksanakan pada bulan Mei sampai bulan Juli 2019 di Rumah Kaca Fakultas Pertanian Universitas Sam Ratulang Manado. Rancangan yang di gunakan dalam penelitian ini menggunakan metode Rancangan Acak Lengkap (RAL) dengan 3 perlakuan dan 3 kali ulangan. Hasil penelitian menunjukkan bahwa pemberian kompos, kotoran sapi dan kotoran ayam memberikan hasil yang baik terhadap keberlanjutan ekologis cacing tanah (Lumbricus rubellus), kesuburan pada bahan induk tanah tambang emas, dan pertumbuhan awal padi gogo varietas unsrat $1 .{ }^{*}$ eprm*
\end{abstract}

Kata kunci : proses dekomposisi, kesuburan tanah, padi gogo varietas unsrat 1

\section{PENDAHULUAN}

\section{Latar Belakang}

Indonesia memiliki berbagai sumber daya alam yang berlimpah, baik itu sumber daya alam hayati maupun sumber daya alam nonhayati. Salah satu sumber daya alam non-hayati di Indonesia yaitu sumber daya mineral, antara lain, emas, minyak bumi dan batu bara. Sumber daya alam merupakan salah satu modal dasar dalam pembangunan nasional, oleh karena itu harus dimanfaatkan sebaik mungkin untuk kepentingan rakyat dengan memperhatikan aspek kelestarian lingkungan. Salah satu kegiatan dalam memanfaatkan sumber daya alam adalah kegiatan penambangan bahan galian (Alyani, 2011).

Bahan organik yang terkandung dalam tanah sangat berpengaruh besar pada perkembangan populasi cacing tanah hal ini diperlukan untuk ketersediaan sumber makanan serta untuk keberlangsungan hidup mahluk hidup lainnya. Kegunaan cacing tanah dapat memperbaiki sifat fisik, kimia dan biologi tanah serta menyuburkan tanah. Adapun tempat hidup cacing tanah, antara lain, di kotoran sapi, kotoran 
ayam dan sampah organik dari rumah tangga. Sampah organik yang mudah terurai, antara lain, daun-daun, sayuran, dan ranting pohon yang sudah membusuk sekaligus menjadi sumber makanan cacing tanah (Sondang, 2013).

Kotoran sapi merupakan bahan yang baik untuk kompos karena relatif tidak terpolusi logam berat dan antibiotik. Kandungan fosfor yang rendah pada pupuk kandang dapat dipenuhi dari sumber lain. Prinsip pembuatan kompos adalah penguraian limbah organik menjadi pupuk organik melalui aktivitas mikroorganisme (Gustiani dan Gunawan, 2002).

Kotoran ayam mengandung unsur Nitrogen yang cukup tinggi, diikuti dengan Kalium, serta Fosfor. Walaupun tingkat keberadaan ketiga unsur ini tergantung dari kondisi ayam itu sendiri seperti kesehatan, diet, serta umur ayam. Jika dibandingkan dengan pupuk kandang lainnya, pupuk kompos dari kotoran ayam mempunyai kandungan hara yang tertinggi. Hal tersebut dikarenakan bagian cair dan bagian padat dari feses ayam tercampur jadi satu. Unsur haranya saja tiga kali lipat lebih banyak dari jenis pupuk lain.

Kompos organik merupakah hasil pelapukan, antara lain, dari dedaunan, jerami alang-alang, rumput-rumputan, serta kotoran hewan. Peran bahan organik yang telah menjadi kompos terhadap sifat fisik tanah di antaranya merangsang granuasi, memperbaiki aerasi tanah dan meningkatkan kemampuan menahan air. Terhadap sifat kimia tanah adalah meningkatkan kapasitas tukar kation sehingga mempengaruhi serapan hara oleh tanaman (Gaur,1980). Pemberian pupuk kompos dapat berfungsi sebagai sumber unsur hara tanah, memperbaiki struktur tanah, porositas tanah, daya menahan air tanah. Selanjutnya menurut Hardjowigeno (2003), tanahtanah yang sangat miskin hara sangat baik bila dipupuk dengan bahan pupuk organik dalam hal ini kompos. Bahan untuk kompos dapat berupa sampah atau sisa-sisa tanaman tertentu (jerami dan lain-lain).

\section{Rumusan Masalah} adalah

Perumusan masalah dalam penelitian ini

1. Bagaimana pengaruh sebelum dan sesudah perlakuan kompos terhadap bahan induk tanah tambang emas.
2. Apakah terdapat perbedaan keberlanjutan ekologis cacing tanah Lumbricus rubellus pada bahan induk tanah tambang emas dengan tanpa perlakuan kompos.

3. Bagaimana pengaruh sebelum dan sesudah perlakuan kompos dan cacing tanah Lumbricus rubellus bahan induk tanah tambang emas terhadap pertumbuhan awal benih padi gogo varietas unsrat 1.

\section{Tujuan Penelitian}

Adapun tujuan dilakukannya penelitian ini diantaranya adalah:

1. Untuk dapat menganalisis pengaruh sebelum dan sesudah perlakuan kompos terhadap bahan induk tanah tambang emas

2. Untuk dapat mengetahui perbedaan berkelanjutan ekologis cacing tanah Lumbricus rubellus pada bahan induk tanah tambang emas dengan tanpa perlakuan kompos.

3. Untuk dapat menganalisis pengaruh sebelum dan sesudah perlakuan kompos dan cacing tanah Lumbricus rubellus pada bahan induk tanah tambang emas terhadap pertumbuhan awal benih padi gogo varietaa unsrat 1 .

\section{Manfaat Penelitian}

Manfaat penelitian ini memiliki beberapa kegunaan, antara lain:

1. Secara ilmiah dapat memberikan informasi terkait keberlanjutan cacing tanah Lumbricus rubellus pada bahan induk tanah tambang emas dengan pemberian kompos.

2. Secara praktis dapat memberikan saran alternatif pengelolaan bahan induk tanah tambang emas yang terabaikan.

\section{METODE PENELITIAN}

\section{Tempat dan Waktu Penelitian}

Penelitian ini dilaksanakan di Rumah Kaca Fakultas Pertanian Universitas Sam Ratulangi Manado dengan waktu penelitian dilaksanakan 3 bulan mulai bulan Mei hingga bulan Juli 2019 .

\section{Bahan dan Alat}

Bahan yang digunakan dalam penelitian ini adalah media tanah, bahan induk tanah tambang emas, kompos, cacing tanah, kotoran hewan (kotoran sapi dan kotoran ayam). Dan juga kertas label, zat -zat kimia yaitu larutan H_2 (SO) 4, 
larutan $\mathrm{NaOH} 10 \mathrm{~N}$, larutan $\mathrm{HCL} 0,1 \mathrm{~N}$ untuk analisis $\mathrm{N}$-total. Zat-zat kimia yaitu larutan ekstratan NH4F $0,03 \mathrm{~N}$, larutan ekstratan HCL $0,025 \mathrm{~N}$ untuk analisis kandungan $\mathrm{P}$ dengan metode Bray I. Zat-zat kimia yaitu larutan K2Cr2O7 10 gr, larutan H2SO4pekat (96\%), larutan $\mathrm{BaCl} 2100 \mathrm{ml}$ untuk analisis $\mathrm{C}$-organik dengan metode Walkley and Black.

Alat-alat yang digunakan dalam penelitian ini antara lain : Mesin penghancur kompos, kotak toples transparan, ayakan, thermometer, EM4, gula pasir, skop kecil, timbangan biasa, timbangan elektrik, alat tulis, penumbuk tanah, tabung reaksi, pipet, beaker glass, cawan petri dan $\mathrm{pH}$ meter.

\section{Rancangan Percobaan}

Penelitian menggunakan metode percobaan Rancangan Acak Lengkap (RAL) metode ini biasa digunakan untuk media atau tempat percobaan yang seragam atau homogen sehingga metode ini banyak digunakan untuk percobaan laboratorium, rumah kaca, dan peternakan. (Sastrosupadi, 2000). Metode RAL dilakukan dengan cara 3 perlakuan dan 3 kali ulangan.

Cacing tanah Lumbricus rubellus dewasa yang digunakan memiliki kisaran berat 0,8 -1 g. Cacing dipelihara dalam kotak toples transparan berisi media yang terdiri dari tanah bahan induk tanah tambang emas, kompos dan kotoran sapi, kotoran ayam dengan perbandingan 4:1:1 $(4 \mathrm{~kg}$ tanah tambang emas, $1 \mathrm{~kg}$ kotoran sapi dan kotoran ayam, $1 \mathrm{~kg}$ kompos).

Jumlah cacing tanah yang dimasukkan dalam kotak toples transparan sesuai dengan perlakuan yang sama pada setiap sumber pakan, masing- masing 5 individu tanpa perlakuan (A0, B0), masing-masing 10 individu (A1, B1) dan masing-masing 15 individu (A2, B2), untuk dapat mengamati perkembangan cacing tanah dalam kotak toples transparan selama 1 bulan. Pengukuran $\mathrm{pH}$ tanah dilakukan pada awal dan akhir percobaan.

Adapun susunan perlakuan sebagai berikut:

\section{Media Cacing:}

a. $\mathrm{A}=$ Kotoran ayam + kompos + cacing tanah

b. $\mathrm{B}=$ Kotoran sapi + kompos + cacing tanah

Perlakuan:

$\mathrm{A} 0$ dan $\mathrm{B} 0=$ Bahan induk tanah tambang emas tanpa pakan cacing (kontrol)
A1 dan $\mathrm{A} 2=$ Bahan induk tanah tambang emas + Kotoran ayam + Kompos + Cacing Tanah B1 dan $\mathrm{B} 2=$ Bahan induk tanah tambang emas + Kotoran sapi + Kompos + Cacing Tanah

2. Populasi atau jumlah cacing tanah:

A0 dan B0 masing-masing 5 ekor cacing tanah (Kontrol) tanpa pakan cacing tanah, A1 dan B1 masing-masing 10 ekor cacing tanah, A2 dan $\mathrm{B} 2=15$ ekor cacing tanah, didapat 3 perlakuan kombinasi, setiap perlakuan kombinasi diulang sebanyak 3 kali sehingga diperlukan 27 kotak toples transparan percobaan.

1. Tahap Pengomposan

\section{Prosedur Penelitian}

a. Pemilahan sampah: Pada tahap ini dilakukan pemisahan sampah dari sampah an-organik (barang berbahaya). Pemilahan dilakukan dengan teliti karena menentukan kelancaran proses dan mutu kompos yang dihasilkan.

b. Pengecil ukuran : pengecil ukuran dilakukan untuk memperluas permukaan sampah, sehingga sampah dapat dengan mudah dan cepat didekomposisi menjadi kompos. Pengecil ukuran dilakukan dengan menggunakan mesin pencacah kompos.

c. Penyusunan tumpukan: Bahan yang telah melewati tahap pemilahan dan pengecil ukuran kemudian disusun menjadi tumpukan. Desain penumpukan yang digunakan adalah desain memanjang dengan dimensi panjang $\times$ lebar $x$ tinggi $=1 \mathrm{~m} \times 1 \mathrm{~m} \times 1 \mathrm{~m}$.

d. Pembalikan : pembalikan dilakukan untuk membuang panas yang berlebihan, memasukkan udara segar ke dalam tumpukan bahan, meratakan proses pelapukan disetiap bagian tumpukan, meratakan pemberian air, serta membantu menghancurkan bahan menjadi partikel-partikel kecil.

e. Penyiraman: Pembalikan dilakukan terhadap bahan baku dan tumpukan yang terlalu kering (kelembaban kurang dari 50\%). Secara manual perlu tidaknya penyiraman dilakukan dengan memeras segenggam bahan dari bagian dalam tumpukan. Apa bila pada saat digenggam kemudian diperas tidak keluar air, maka tumpukan sampah ditambahkan air. Sedangkan sebelum diperas sudah keluar air, maka tumpukan terlalu basah maka dilakukan pembalikan. 
f. Pematangan: Setelah pengomposan berjalan 30 hari, suhu tumpukan akan menurun hingga mendekati suhu ruangan. Pada saat itu tumpukan telah lapuk, berwarna coklat tua atau kehitaman. Kompos masuk pada tahap pematangan selama 14 hari.

g.Penyaringan: dilakukan untuk memproleh ukuran partikel kompos sesuai dengan kebutuhan serta untuk memisahkan bahanbahan yang tidak dapat dikomposkan yang lolos dari proses pemilahan diawal proses. Bahan yang belum terkomposkan dikembalikan kedalam tumpukan yang baru, sedangkan bahan yang tidak terkomposkan dibuang sebagai residu.

2. Tahap Perlakuan

a. Bahan induk tanah tambang emas ditimbang dengan perbandingan $4: 1: 1(4 \mathrm{~kg}$ bahan induk tanah tambang emas $+1 \mathrm{~kg}$ kompos $+1 \mathrm{~kg}$ kotoran (ayam atau sapi)) disatukan dalam 1 kotak toples teransparan.

b. Jumlah populasi cacing tanah pada A0 dan B0 sebanyak masing-masing 5 ekor cacing tanah (kontrol) tanpa pakan cacing tanah, A1 dan B1 masing-masing sebanyak 10 ekor cacing tanah, A2 dan B2 masingmasing sebanyak 15 ekor cacing tanah yang dimasukan dalam kotak toples transparan yang sudah disediakan lalu dipelihara selama 30 hari.

c. Semua perlakuan telah dicampurkan jadi satu (bahan induk tanah tambang emas + kompos + kotoran ayam + cacing tanah dan bahan induk tanah tambang emas + kompos + kotoran sapi + cacing tanah) dan telah dipelihara cacing tanah didalam kotak toples transparan selama 1 bulan.

d. Selanjutnya tanah tersebut ditanami padi gogo varietas unsrat 1 untuk diamati tinggi tanaman dan jumlah daun selama 1 bulan.

\section{Parameter Pengamatan}

Pengamatan dilakukan setelah proses dekomposisi selama 4 minggu. Parameter yang diamati yaitu: Populasi cacing tanah (ekor), kadar C-organik (\%) awal dan akhir, kadar Ntotal (\%) awal dan akhir, P-tersedia (mg kg-1) awal dan akhir dan $\mathrm{pH}$ meter awal dan akhir. Dan selanjutnya tanah akan di tanam tanaman padi (padi gogo jenis varietas unsrat 1) untuk dilakukan pengamatan terhadap proses pertumbuhan tanaman padi selama umur satu bulan dengan perlakuan 3 kali ulangan dan masing-masing kotak toples transparan di tanam 5 biji tanaman padi gogo jenis varietas unsrat 1. Pengukuran yang dilakukan dalam pengamatan antara lain: Tinggi Tanaman dan Jumlah Daun.

\section{HASIL DAN PEMBAHASAN}

\section{Analisis Populasi Cacing Tanah Lumbricus Rubellus}

Hasil analisis populasi cacing tanah Lumbricus rubellus menunjukkan bahwa dalam perlakuan kompos kotoran ayam dan kotoran sapi dengan memelihara cacing tanah Lumbricus rubellus selama 1 bulan sehingga dapat melihat atau mengindentifikasi proses perkembangan dan pertumbuhan cacing tanah Lumbricus rubellus melalui pencatatan jumlah cacing tanah, berat cacing tanah dan panjang cacing tanah.

Perlakuan kompos yang dilakukan dan tanpa perlakuan kompos sebagai kontrol dapat dilihat bahwa perlakuan kompos + kotoran sapi + cacing tanah memberikan hasil yang sangat baik dan respon cacing tanah Lumbricus rubellus pada perlakuan tersebut dibandingan dengan perlakuan kompos + kotoran ayam dan tanpa perlakuan kompos.

Perlakuan kompos + kotoran ayam tidak di sukai oleh cacing tanah Lumbricus rubellus karena kotoran ayam mengandung zat amoniak yang tinggi dan pula pada tanpa perlakuan kompos dimana tidak terdapat ketersediaan makanan bagi cacing tanah Lumbricus rubellus dan terdapat bahan induk tanah tambang emas tanpa perlakuan pakan cacing tanah Lumbricus rubellus. Tanah tambang emas bersifat masam dan tidak ada unsur hara. Jumlah populasi cacing tanah Lumbricus rubellus dapat dilihat pada Tabel 1. 
Tabel 1. Hasil Penelitian Pengukuran Populasi Cacing Tanah

\begin{tabular}{ccccccc}
\hline Perlakuan & \multicolumn{2}{c}{$\begin{array}{c}\text { Jumlah } \\
\text { cacing tanah }\end{array}$} & \multicolumn{2}{c}{$\begin{array}{c}\text { Berat cacing } \\
\text { tanah }(\mathrm{gr})\end{array}$} & \multicolumn{2}{c}{$\begin{array}{c}\text { Panjang cacing } \\
\text { tanah }(\mathrm{cm})\end{array}$} \\
\hline \multicolumn{1}{c}{ Awal } & Akhir & Awal & Akhir & Awal & Akhir \\
\hline A0 & 5 & 4 & 4 & 3 & 12 & 12 \\
A0 & 5 & 4 & 4 & 3 & 12 & 12 \\
A0 & 5 & 4 & 4 & 3 & 12 & 12 \\
A1 & 10 & 10 & 7 & 6 & 14 & 14 \\
A1 & 10 & 10 & 7 & 6 & 14 & 14 \\
A 1 & 10 & 10 & 7 & 6 & 14 & 14 \\
A2 & 15 & 14 & 13 & 12 & 14 & 14 \\
A2 & 15 & 12 & 13 & 12 & 14 & 14 \\
A2 & 15 & 13 & 13 & 12 & 14 & 14 \\
B0 & 5 & 4 & 4 & 3 & 14 & 14 \\
B0 & 5 & 4 & 4 & 3 & 14 & 14 \\
B0 & 5 & 4 & 4 & 3 & 14 & 14 \\
B1 & 10 & 10 & 7 & 8 & 14 & 14 \\
B1 & 10 & 10 & 7 & 8 & 14 & 14 \\
B1 & 10 & 10 & 7 & 8 & 14 & 14 \\
B2 & 15 & 15 & 13 & 15 & 14 & 14 \\
B2 & 15 & 15 & 13 & 15 & 14 & 14 \\
B2 & 15 & 15 & 13 & 15 & 14 & 14 \\
\hline
\end{tabular}

Tabel 1 menunjukkan bahwa hasil analisis jumlah cacing tanah terdapat perbedaan kelanjutan ekologis cacing tanah Lumbricus rubellus pada bahan induk tanah tambang emas dengan tanpa perlakuan kompos yaitu bahan induk tanah tambang yang diberikan perlakuan kompos nilainya tinggi daripada perlakuan tanpa kompos. Pakan yang diberikan yaitu kotoran ayam dan kotoran sapi

Urutan perlakuan yang memberikan nilai tertinggi sampai terendah pada akhir sesudah pengamatan jumlah cacing tanah yaitu B2 (15), A2 (14), B1 (10), A1(10), A0 (4), B0 (4). Nilai jumlah cacing tanah Lumbricus rubellus tertinggi pada perlakuan B2 (tanah tambang emas + kompos + kotoran sapi + cacing tanah 15 ekor) dan yang rendah pada perlakuan A0 (tanah tambang emas + cacing tanah 5 ekor) dan B0 (tanah tambang emas + cacing tanah 5 ekor) tanpa pemberian pakan (kontrol). jumlah cacing tanah Lumbricus rubellus dapat dilihat pada Gambar 1.

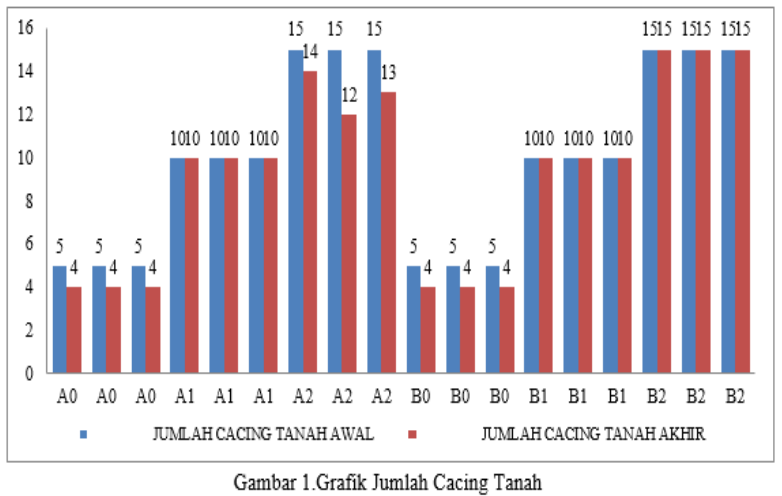

Cacing tanah Lumbricus rubellus yang sudah dipelihara selama 30 hari akan menghasilkan kokon. Terdapat pada setiap jenis perlakuan untuk jumlah kokon cacing tanah Lumbricus rubellus. Jumlah kokon cacing tanah pada perlakuan dapat dilihat pada Gambar 2.

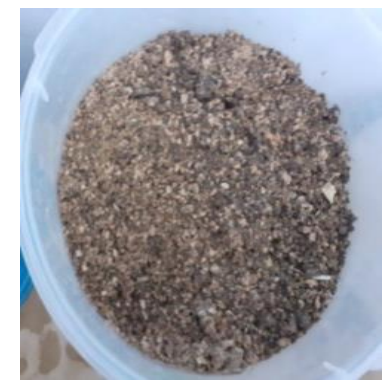

Tanpa perlakuan

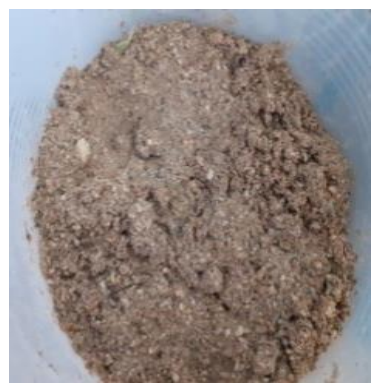

Perlakuan A1

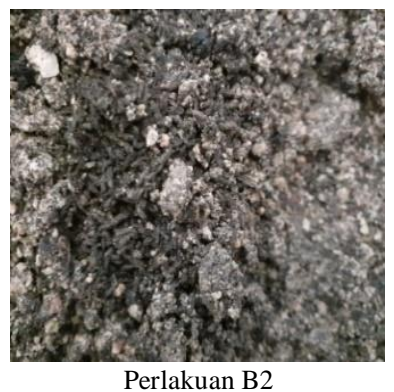

Gambar 2. Jumlah Kokon Cacing Tanah Pada Perlakuan

Hasil penelitian pada pengamatan pertama di minggu pertama jumlah kokon yang dihasilkan masih sedikit dan jumlah kokon yang tertinggi dijumpai pada perlakuan B2 20 butir kemudian diikuti dengan B1, A1, A2. Jumlah kokon yang dihasilkan masih sedikit karena pada awal pemeliharaan, cacing tanah Lumbricus rubellus akan menggunakan nutrisi yang dari media itu untuk aktivitas tubuh yaitu reproduksi.

Hasil penelitian pada pengamatan kedua di minggu kedua jumlah kokon meningkat dari minggu pertama. Jumlah kokon yang tertinggi pada perlakuan B2, B1 (tanah tambang emas + kompos + kotoran sapi + cacing tanah) dibandingkan dengan perlakuan A1, A2 (tanah tambang emas + kompos + kotoran ayam + cacing tanah) dan A0, B0 (tanah tambang emas + cacing tanah) tanpa pakan cacing sebagai kontrol.

Hasil penelitian pada pengamatan ketiga di minggu ketiga jumlah koko meningkat setelah $\mathrm{B} 2$, B1 dan dapat tersusul oleh A1, A2. Dalam penelitian ini terlihat pengaruh yang nyata dalam setiap perlakuan yang dilakukan dalam 
pemeliharaan cacing tanah selama satu bulan. Pakan adalah hal yang terpenting dalam memelihara cacing tanah. Pertumbuhan cacing tanah akan berhasil apabila jumlah dan jenis pakannya dapat dicerna oleh cacing tanah tersebut dengan baik.

\section{Analisis Bahan Induk Tanah}

Tambang Emas dan Kompos

Hasil analisis pengaruh sebelum dan sesudah perlakuan kompos terhadap bahan induk tanah tambang emas pada pertumbuhan awal pemberian benih padi gogo varietas unsrat 1 yakni pada sebelum dan sesudah perlakuan kompos diambil bahan induk tanah tambang emas untuk dapat dianalisis di laboratorium ilmu tanah Fakultas Pertanian Unsrat Manado untuk dapat melihat pengaruh perlakuan kompos sebelum dan sesudah. Dalam perlakuan ini yaitu bahan induk tanah tambang emas tanpa perlakuan $(\mathrm{A} 0, \mathrm{~B} 0)$ sebangai kontrol, perlakuan $\mathrm{A} 1$, A2 (bahan induk tanah tambang emas + kompos + kotoran ayam + cacing tanah dan perlakuan B1,B2 (bahan induk tanah tambang emas + kompos + cacing tanah).

Perlakuan kompos ini terdapat pengaruh sebelum dan sesudah perlakuan kompos terhadap bahan induk tanah tambang emas pada perlakuan kompos B1,B2 (bahan induk tanah tambang emas + kompos + kotoran sapi + cacing tanah) memberikan perbedaan dalam hasil analisis sebelum dan sesudah perlakuan kompos dan pula terdapat perbedaan pada pertumbuhan awal pemberian benih padi gogo varietas unsrat 1 dimana pertumbuhan benih padi gogo varietas unsrat 1 pada perlakuan kompos $(\mathrm{B} 1, \mathrm{~B} 2)$ kotoran sapi pertumbuhannya lebih baik karena banyak mengandung bahan organik dan kokon cacing tanah dibandingkan dengan perlakuan kompos (A1,A2) kotoran ayam. Dari hasil analisis sebelum dan sesudah perlakuan kompos terhadap bahan induk tanah tambang emas dapat dilihat pada Tabel 2 dan Tabel 3.

Tabel 2. Analisis pH dan C-organik Tanah Metode Walky and Black

\begin{tabular}{|c|c|c|c|c|c|}
\hline $\mathrm{NO}$ & Kode sampel & $\begin{array}{l}\mathrm{pH} \mathrm{H}_{2} \\
01: 2,5\end{array}$ & Kriteria & $\%$ & Kriteria \\
\hline 1 & A1 Sebelum & 7,4 & Netral & 10,42 & Sangat Tingg \\
\hline 2 & A1 Sesudah & 7,3 & Netral & 9,03 & Sangat Tingg \\
\hline 3 & A2 Sebelum & 7,3 & Netral & 10,77 & Sangat Tingg \\
\hline 4 & A2 Sesudah & 7,4 & Netral & 8,69 & Sangat Tingg \\
\hline 5 & B1 Sebelum & 7,6 & Netral & 14,24 & Sangat Tingg \\
\hline 6 & B1 Sesudah & 7,5 & Netral & 14,94 & Sangat Tingg \\
\hline 7 & B2 Sebelum & 7,7 & Netral & 13,90 & Sangat Tingg \\
\hline 8 & B2 Sesudah & 7,6 & Netral & 14,59 & Sangat Tingg \\
\hline 9 & Kontrol A0 Awal & 6,6 & Netral & 1,39 & Rendah \\
\hline 10 & Kontrol A0 Akhir & 7,4 & Netral & 1,46 & Rendah \\
\hline 11 & Kontrol B0 Awal & 6,6 & Netral & 1,39 & Rendah \\
\hline 12 & Kontrol B0 Akhir & 7,4 & Netral & 1,46 & Rendah \\
\hline
\end{tabular}

Tabel 3. Analisis N-Total Tanah Metode Kjedahl, $\mathrm{P}_{2} \mathrm{O}_{5}$ tersedia tanah ekstraksi Bray 1 dan $\mathrm{K}_{2} \mathrm{O}$ tersedia tanah ekstraksi Bray 1 Metode $\quad \mathrm{P}_{2} \mathrm{O}_{5}$ tersedia $\mathrm{K}_{2} \mathrm{O}$ tersedia Kjedahl ekstraksi Bray tanah ekstrak

\begin{tabular}{|c|c|c|c|c|}
\hline & & $\begin{array}{l}\text { letode } \\
\text { jedahl }\end{array}$ & $\begin{array}{l}\mathrm{P}_{2} \mathrm{O}_{5} \text { tersedia } \\
\text { ekstraksi Bray } \\
1\end{array}$ & $\begin{array}{c}\mathrm{K}_{2} \mathrm{O} \text { tersedia } \\
\text { tanah ekstrak } \\
\text { si Bray } 1\end{array}$ \\
\hline $\begin{array}{l}\text { No Kode } \\
\text { sampel }\end{array}$ & & Kriteria & Ppm Krteria & Ppm \\
\hline $\begin{array}{ll}1 & \text { A1 } \\
& \text { Sebelum }\end{array}$ & 0,90 & $\begin{array}{l}\text { Sangat } \\
\text { Tinggi }\end{array}$ & 34,92 Tinggi & 30,60 \\
\hline $\begin{array}{ll}2 & \text { A1 } \\
& \text { Sesudah }\end{array}$ & 0,78 & $\begin{array}{l}\text { Sangat } \\
\text { Tinggi }\end{array}$ & 26,18 Tinggi & 35,41 \\
\hline $\begin{array}{ll}3 & \text { A2 } \\
& \text { Sebelum }\end{array}$ & 0,93 & $\begin{array}{l}\text { Sangat } \\
\text { Tinggi }\end{array}$ & 35,29 Tinggi & 33,71 \\
\hline $\begin{array}{ll}4 & \text { A2 } \\
& \text { Sesudah }\end{array}$ & 0,75 & $\begin{array}{l}\text { Sangat } \\
\text { Tinggi }\end{array}$ & 23,55 Sedang & 36,65 \\
\hline $\begin{array}{ll}5 & \text { B1 } \\
& \text { Sebelum }\end{array}$ & 1,23 & $\begin{array}{l}\text { Sangat } \\
\text { Tinggi }\end{array}$ & 30,92 Tinggi & 29,10 \\
\hline $\begin{array}{ll}6 & \text { B1 } \\
& \text { Sesudah }\end{array}$ & 1,29 & $\begin{array}{l}\text { Sangat } \\
\text { Tinggi }\end{array}$ & 21,18 Sedang & 26,05 \\
\hline $\begin{array}{ll}7 & \text { B2 } \\
& \text { Sebelum }\end{array}$ & 1,20 & $\begin{array}{l}\text { Sangat } \\
\text { Tinggi }\end{array}$ & 31,29 Tinggi & 28,00 \\
\hline $\begin{array}{ll}8 & \text { B2 } \\
& \text { Sesudah }\end{array}$ & 1,26 & $\begin{array}{l}\text { Sangat } \\
\text { Tinggi }\end{array}$ & 23,55 Sedang & 28,55 \\
\hline $9 \begin{array}{c}\text { Kontrol } \\
\text { A0 Awal }\end{array}$ & 0,12 & Rendah & 10,92 Rendah & 16,25 \\
\hline $\begin{array}{c}10 \text { Kontrol } \\
\text { A0 Akhir }\end{array}$ & 0,13 & Rendah & 11,18 Rendah & 18,42 \\
\hline $11 \quad \begin{array}{c}\text { Kontrol } \\
\text { B0 Awal }\end{array}$ & 0,12 & Rendah & 10,92 Rendah & 16,25 \\
\hline $\begin{array}{c}\text { Kontrol } \\
\text { B0 } \\
\text { Akhir } \\
\end{array}$ & 0,13 & Rendah & 11,18 Rendah & 18,42 \\
\hline
\end{tabular}

Tabel 2 dan Tabel 3 menunjukkan bahwa hasil analisis tanah terdapat perbedaan kandungan unsur hara sebelum dan sesudah penanaman padi gogo varietas unsrat 1 . Hal ini diduga disebabkan adanya pengaruh serapan hara yang diambil tanaman saat pertumbuhan tanaman dan proses yang ada dalam tanah akibat adanya pengaruh pemberian cacing tanah Lumbricus rubellus. Cacing tanah Lumbricus rubellus berpengaruh pada proses yang berlangsung dalam tanah sehingga pertumbuhan tanaman padi gogo menunjukkan adanya perbedaan. Tanah tambang yang dijadikan media dalam penelitian ini mempunyai kandungan unsur hara yang sangat rendah. Tanah-tanah seperti ini dengan kandungan hara yang sangat rendah perlu penambahan unsur hara agar tanaman dapat bertumbuh dengan baik sehingga produksi tanaman meningkat. Tanah dengan kandungan unsur hara yang rendah apabila diadakan pemupukan maka tanah maupun tanaman akan respons terhadap pemupukan. 


\section{Pertumbuhan A wal Tanaman Padi Gogo Varietas Unsrat 1 Setelah Aplikasi Beberapa Perlakuan Cacing Tanah}

\section{Tinggi Tanaman Padi Gogo Varietas Unsrat 1}

Hasil penelitian pengukuran tinggi tanaman padi gogo varietas unsrat 1 akibat aplikasi beberapa cacing tanah Lumbricus rubellus pada bahan induk tanah tambang emas pada berbagai tahap perlakuan selama satu bulan dapat dilihat pada Gambar 2.
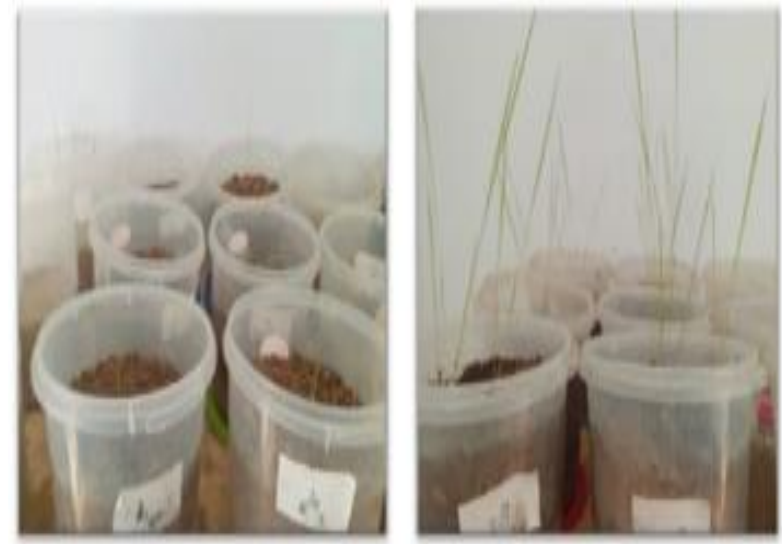

Gambar 2. Aplikasi Tanaman Padi Gogo Varietas Unsrat 1

Hasil penelitian menunjukkan bahwa intraksi antara pemberian perlakuan cacing tanah Lumbricus rubellus dan pada pakan cacing tanah Lumbricus rubellus tidak menunjukkan pengaruh yang nyata pada setiap minggu pengamatan. Pengaruh nyata hanya pada jenis-jenis pakan yang diberikan. Pengamatan pemberian beberapa jenis perlakuan dan jumlah pakan cacing tanah Lumbricus rubellus terhadap tinggi tanaman padi gogo varietas Unsrat 1 dapat dilihat pada Tabel 4.

Tabel 4. Pengukuran Tinggi Tanaman Padi Gogo Varietas Unsrat 1

\begin{tabular}{ccccc}
\hline & \multicolumn{3}{c}{ TINGGI TANAMAN PADI $(\mathrm{cm})$} \\
\cline { 2 - 4 } PERLAKUAN & 1 MST & 2 MST & 3MST & 4MST \\
\hline A0 & 4,00 & 7,00 & 15,00 & 23,00 \\
A0 & 3,00 & 8,00 & 15,00 & 24,00 \\
A0 & 3,00 & 7,00 & 16,00 & 25,00 \\
A1 & 3,00 & 8,00 & 12,00 & 20,00 \\
A1 & 4,00 & 7,05 & 11,00 & 20,13 \\
A1 & 2,00 & 5,00 & 11,00 & 19,00 \\
A2 & 3,00 & 7,00 & 12,00 & 21,00 \\
A2 & 3,00 & 8,00 & 14,00 & 23,00 \\
A2 & 2,05 & 6,00 & 13,00 & 22,00 \\
B0 & 8,00 & 13,00 & 20,00 & 29,00 \\
B0 & 8,05 & 14,00 & 20,05 & 30,00 \\
B0 & 7,00 & 14,00 & 20,00 & 29,00 \\
B1 & 8,00 & 15,00 & 23,00 & 34,00 \\
B1 & 8,05 & 13,00 & 21,00 & 32,00 \\
B1 & 9,00 & 13,00 & 22,00 & 31,12 \\
B2 & 9,00 & 16,00 & 25,00 & 38,00 \\
B2 & 7,00 & 16,00 & 26,00 & 39,05 \\
B2 & 9,00 & 17,00 & 28,00 & 40,00 \\
\hline
\end{tabular}

Tabel 4 menunjukkan bahwa hasil penelitian pemberian jenis perlakuan B1 dan B2 (tanah tambang emas + kompos + kotoran sapi+ cacing tanah) pada setiap minggu perlakuan menunjukkan nilai tertinggi di bandingan dengan perlakuan A1 dan A2 (tanah tambang emas + kompos + kotoran ayam + cacing tanah).

Tingginya nilai tinggi tanaman pada perlakuan B1 dan B2 disebabkan karena perlakuan kompos B1 dan B2 memiliki kandungan hara yang lebih tinggi karena aktivitas pada cacing tanah Lumbricus rubellus meningkat dan dapat memberikan kokon atau kotoran cacing tanah Lumbricus rubellus yang banyak dan menyediakan unsur hara sehingga dapat meningkatkan pertumbuhan tanaman padi sangat baik pada phase pertumbuhan. Sedangkan pada perlakuan kompos A1 dan A2 menunjukkan bahwa kotoran ayam memiliki zat amoniak yang tinggi dan tidak disukai oleh cacing tanah Lumbricus rubellus sehingga mempengaruhi pertumbuhan tanaman padi.

\section{Jumlah Daun Tanaman Padi Gogo Varietas Unsrat 1}

Hasil pengamatan jumlah daun tanaman padi gogo varietas Unsrat 1 akibat pemberian beberapa jenis perlakuan kompos pada beberapa jumlah pemeliharaan cacing tanah Lumbricus rubellus dapat dilihat pada Gambar 3.

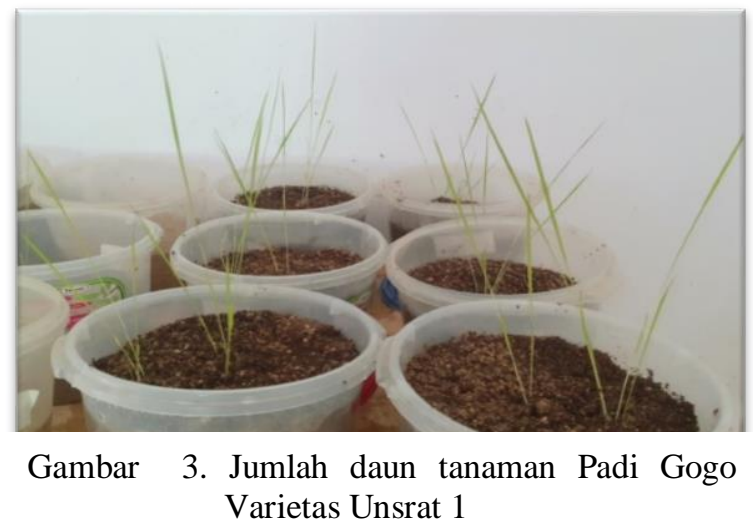

Hasil penelitian menunjukkan bahwa jumlah daun tanaman padi menunjukkan bahwa intraksi pemberian beberapa jenis perlakuan cacing tanah Lumbricus rubellus dan pakan pada perlakuan cacing tanah Lumbricus rubellus tidak menunjukkan pengaruh yang nyata pada setiap minggu pengamatan, pengaruh nyata hanya pada jenis pakan yang diberikan. 


\section{KESIMPULAN DAN SARAN}

\begin{abstract}
Kesimpulan
Berdasarkan hasil penelitian uji berkelanjutan ekologi cacing tanah Lumbricus rubellus pada bahan induk tanah tambang emas dengan memanfaatkan kompos dapat disimpulkan bahwa :

1. Hasil analisis keberlanjutan ekologis cacing tanah Lumbricus rubellus pada bahan induk tanah tambang emas dengan perlakuan kompos terdapat perbedaan yakni perlakuan kompos B1, B2 kotoran sapi memberikan hasil yang baik terhadap kesuburan tanah dibandingkan dengan tanpa perlakuan kompos.

2. Hasil analisis pengaruh sebelum dan sesudah perlakuan kompos terhadap bahan induk tanah tambang emas dan pertumbuhan awal pemberian benih padi gogo varietas unsrat 1 pada perlakuan kompos B1, B2 kotoran sapi banyak terdapat kokon cacing tanah Lumbricus rubellus meningkat dan pertumbuhan padi gogo varietas unsrat 1 lebih baik.
\end{abstract}

\section{Saran}

1. Secara ilmiah hasil penelitian menunjukkan bahwa keberadaan cacing tanah Lumbricus rubellus pada bahan induk tanah tambang emas dengan perlakuan kompos B1, B2 kotoran sapi dapat berkelanjutan secara ekologis.

2. Secara praktis hasil penelitian ini memberikan saran alternatif pengelolaan bahan induk tanah tambang emas yang terbiarkan dengan memanfaatkan kompos B1, B2 kotoran sapi untuk dapat meningkatkan kesuburan tanah tambang emas.

\section{DAFTAR PUSTAKA}

Ahyani, M. 2011. Pengaruh kegiatan penambangan emas terhadap kondisi kerusakan tanah pada wilayah pertambangan rakyat di Bombana Provinsi Sulawesi Tenggara. Semarang, UNDIP.

Gaur, A.C. 1980. Improving Soil Fertility Through Organic Recycling. Fundamental Of Composting FAO/UNDP Regional Project RAS/75/004. Project Field Document (13).

Gustiani, E dan Gunawan A. 2002. Membuat kompos kotoran sapi lebih berkualitas. http://www.pustaka.litbang.deptan.go.id/pu blikasi/wr274054.pdf. Tanggal Akses November 2019.

Hardjowigeno, S. 2003. Ilmu Tanah. Akademika Pressindo. Jakarta. 286 halaman.

Mulyanto, B. 2008. Kelembagaan Pengelolaan Kawasan Pasca Tambang. In Makalah Seminar dan Workshop Reklamasi dan Pengelolaan Kawasan Pasca penutupan Tambang. Pusdi Reklatam, Bogor (Vol. 22).

Sastrosupadi, A. 2000. Rancangan Percobaan Praktis Bidang Pertanian (Edisi Revisi) Halaman 53. Penerbit Kanisius. Yogyakarta.

Sondang, 2013. Keunikan Makrofauna Cacing Tanah.http://syekhfanismd.lecture.ub.ac.id/ files/2013/03/CACING-TANAH.pdf. Akses Tanggal 27 November 2019. 